CADERNOS GESTÃo PÚBLICA E CIDADANIA

\title{
PROVE - UMA EXPERIÊNCIA DE IMPLANTAÇÃO DE MICROEMPRESAS AGROINDUSTRIAIS
}

Humberto Marques Filho

Maria Dilma Guedes 


\section{Os Autores}

\section{Humberto Marques Filho}

Doutor em Administração de Empresas pela Universidade de Navarra Espanha. Professor da Universidade Federal da Paraíba. Diretor Científico/Didático do Instituto de Ensino superior de Pesquisa Lynaldo Cavalcanti.

\section{Maria Dilma Guedes}

Mestre em Administração de Empresas pela Universidade Federal da Paraíba. Professora da Universidade Estadual da Paraíba. 


\section{ÍNDICE}

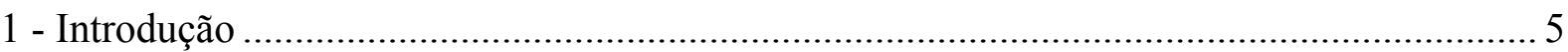

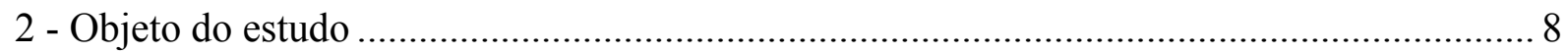

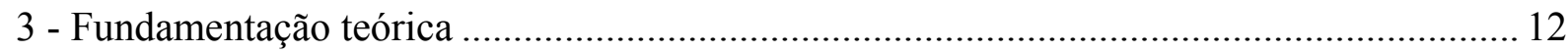

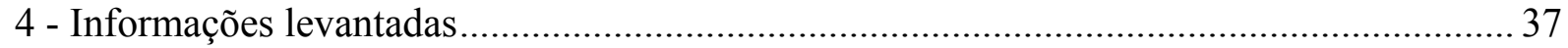

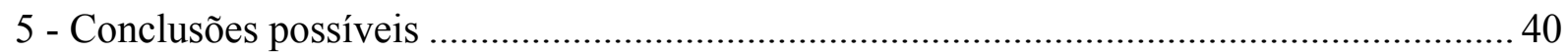

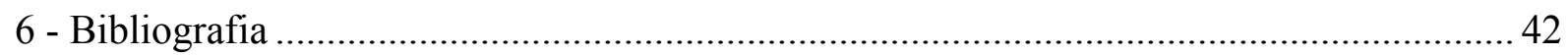




\section{INTRODUÇÃO}

A todo momento estão "nascendo" novas empresas, graças à iniciativa de pessoas que se dispõem a assumir os riscos inerentes ao próprio empreendimento e que podem vir a ter um papel importante no desenvolvimento econômico do país.

Infelizmente, muitas dessas empresas não chegam a completar seis meses de vida, frustrando o sonho de grande parte dos seus "empreendedores".

Estudos, indicam que $50 \%$ de todos os novos micros e pequenos empreendimentos no Brasil, não conseguem passar do primeiro ano de vida. E que, depois de cinco anos, apenas $20 \%$ sobrevivem.

Os mais diversos autores que têm se dedicado ao estudo dessas empresas são unânimes em afirmar que uma das principais causas do insucesso reside no desconhecimento, por parte do futuro empresário, das qualidades necessárias ao bom desempenho do seu papel.

Segundo esses autores, essas qualidades podem ser resumidas como:

- Capacidade para identificar oportunidades

- Habilidade para identificar oportunidades

- Conhecimento do ramo empresarial

- Senso de Organização

- Disposição para tomar decisões

- Faculdade de liderar

- Talento empreendedor

- Independência pessoal

- Otimismo

- Tino empresarial

Em contrapartida, esses mesmos autores acreditam que os empresários que conseguem êxito e que conduzem seus negócios além dos limites médios de sobrevivência, são exatamente aqueles que atendam às características relacionadas 


\section{O QUE SE PRETENDE REALIZAR}

A pesquisa pretendeu analisar o desempenho do PROVE - Programa de Verticalização da Pequena Produção Rural, do governo do Distrito Federal, que incentiva a criação de pequenas agroindústrias nas comunidades rurais da periferia de Brasília.

O Estudo procurou analisar a ação do governo do Distrito Federal com vistas à sensibilização das comunidades periféricas, no sentido de se decidirem pelo envolvimento no esforço de criação dessas microempresas, bem como o desempenho conseguido pelas mesmas.

Por outro lado, tentou identificar as causas do sucesso ou do fracasso das microempresas criadas, face ao cumprimento, ou não, das características anteriormente relacionadas.

Por fim tentou identificar procedimentos que deverão ser adotados pelo governo do Distrito Federal, no caso de constatação de deficiências que comprometem a execução do programa e sua continuidade.

Face a realidade do programa, onde a grande maioria dos "empreendedores" são mulheres, pretendeu-se, subsidiariamente, identificar até que ponto as características definidas para o empreendedor homem são válidas para a mulher empreendedora.

\section{POR QUE SE PRETENDEU INVESTIGAR O TEMA}

Diante de inúmeras experiências que vêm sendo desenvolvidas em todo o país, no sentido de incorporar ao setor produtivo, uma significativa parcela da população marginalizada (experiências como as do PROVE, podem ser identificadas como a do PORTOSOL, da prefeitura de Porto Alegre ou do Centro de Comercialização Luiza Motta, do governo da Paraíba) justifica-se, amplamente, um estudo que procure identificar as necessidades que devem ser desenvolvidas naqueles que pretendam participar das mesmas, por um lado e os procedimentos que devem ser adotados pelos responsáveis pela implantação e condução dessas experiências.

\section{COMO PROCUROU FAZER}

A pesquisa tem características de um estudo exploratório e através dela se tentou de início, estabelecer o perfil do empreendedor vinculado ao Programa de Verticalização da Pequena Produção Rural, do Distrito Federal. 
Tal procedimento permitiu a facilitação de informações necessárias à consecução do objetivo secundário, ao ter um conhecimento da distribuição, por gênero, do universos dos empreendedores.

Em seguida, se procurou identificar até que ponto as características, definidas pela literatura como inerentes ao empreendedor e responsáveis pelo êxito ou fracasso das empresas, estão presentes nos participantes do PROVE.

\section{VARIÁVEIS ESTUDADAS}

Em relação ao PERFIL DO EMPREENDEDOR (e da empresa):

- Forma jurídica

- Ano de fundação

- Endereço/bairro

- Número de empregados

- Porte da empresa

- Idade do empresário

- Estado civil

- Grau de instrução

- Horas dedicadas à empresa (por dia)

- Fatores motivadores da decisão de torna-se empresário que fazia antes de criar a empresa

- Dificuldades na criação da empresa

- Facilidades na criação da empresa

- Tipo de produto

- Tipo de matéria prima

- Fonte de suprimento da matéria prima

- Destinação do produto final

\section{Em relação às QUALIDADES DO EMPREENDEDOR:}

- Capacidade de assumir riscos

- Habilidade para identificar oportunidades

- Conhecimento do ramo empresarial

- Senso de Organização 
- Disposição para tomar decisões

- Faculdade de liderar

- Talento para empreender

- Independência pessoal

- Otimismo

- Tino empresarial

\section{FONTES DE DADOS}

Foram utilizados os dados disponíveis no projeto encaminhado ao Programa Gestão Pública \& Cidadania e no Relatório da visita realizar ao PROVE, ao longo do Ciclo de Premiação do ano 1997.

Paralelamente, foram obtidas informações complementares levantadas mediante a aplicação de dois questionários junto aos empreendedores participantes da experiência desenvolvida pelo governo do Distrito Federal.

Os questionários foram aplicados pelo coordenador da pesquisa e por dois alunos do Curso de Mestrado em Administração do Programa de Pós-Graduação em Administração da Universidade Federal da Paraíba, com a colaboração da Secretaria de Agricultura do governo do Distrito Federal.

\section{TRATAMENTO DOS DADOS}

A análise e interpretação dos dados foram realizadas de acordo com as técnicas do método estatístico descritivo, com a utilização apenas de freqüências absoluta e relativa, expressas em gráficos e tabelas.

\section{2 - OBJETO DO ESTUDO}

\section{O PROGRAMA DE VERTICALIZAÇÃO DA PEQUENA PRODUÇÃO RURAL}

\section{Introdução}

Iniciado em outubro de 1995, o Programa de Verticalização da Pequena Produção Agrícola da Secretaria de Agricultura do Distrito Federal é destinado à famílias da área rural com renda per capita abaixo de meio salário mínimo. 
Com os objetivos de inserir o pequeno produtor agrícola no processo produtivo através do beneficiamento de seus produtos in natura, agregando-lhes valor e propiciando a elevação da renda de sua produção - além de gerar empregos no campo, o Programa já colocou em funcionamento aproximadamente 120 agro-industriais.

O Estado, através da Secretaria da Agricultura e suas unidades vinculadas, coordena todas as fases de implantação de cada unidade (seleção da família, assessoria na obtenção do financiamento, projeto físico, compra de equipamentos, treinamento, assessoria no processo produtivo e na comercialização, facilidade na compra de insumos etc.).

\section{Objetivos e Metas}

Um dos objetivos já alcançados pelo programa é a mudança do nível de renda das famílias selecionadas, que antes era de meio salário mínimo per capita e após dois e três meses de implantação das unidades produtivas passou para cerca de dois salários-mínimo per capita.

Outro objetivo é a geração de novos empregos, com o retorno ao campo de família fixadas na periferia das cidades para trabalhar na agroindústria. Para cada membro proprietário produtor tem sido incorporados de um a três novos trabalhadores contratados, atualmente, sem registro em carteira. A Secretaria da Agricultura está tomando providencias para regularizar essa situação. Há também o aumento do consumo dessas famílias com a compra de equipamentos, veículos, telefones, etc.

\section{Inovação}

A inovação do programa está na sua capacidade de operacionalização.

A prática anterior era totalmente segmentada, cada unidade do governo enxergava apenas a sua função. Hoje, sob o comando da Secretaria da Agricultura, todas as unidades atuam de forma integrada.

Outra inovação importante é a capacidade real de se trabalhar com o excluído para incluílo no processo de desenvolvimento, colocando o Estado prioritariamente a seu serviço.

O Estado exerce também papel fundamental de articulador e negociador com outras instâncias governamentais e privadas (CNPq, Carrefour, BNDES, BRB, Ministério da Saúde etc.). 


\section{Fontes de Recursos}

O investimento médio de cada unidade é de $\mathrm{R} \$ 5.000,00$. Caso seja atingida a meta de 300 agro-industriais, será necessário financiamento total de R \$1.500.000,00. Ressalta-se, no entanto, que estes recursos, atualmente do BRB, retornam ao banco no prazo de seis anos a juros de $6 \%$ ao ano.

É importante termos como referência que qualquer banco, público ou privado, considera como a sua pior carteira de empréstimo a carteira social. O PROGER recebeu 130 milhões de reais, mas a Caixa Econômica Federal recusou-se a administrá-la e o Banco do Brasil está "providenciando" há cerca de quatro meses.

Como os outros custos de assessoria técnica, financiamento, fiscalização etc., são custos preexistente do governo, a necessidade de recurso financeiros novos, neste item, é praticamente zero.

A auto sustentabilidade dar-se-á uma vez preenchido os seguintes pré-requisitos: quitação da dívida, alternativas na compra de seus insumos e mercados não dependentes de apoio do governo.

\section{Gerenciamento}

A principal característica do modelo de gestão adotado é a sua estrutura de decisão. Ela se dá em dois níveis básicos: político-institucional e técnico-operacional.

O nível político-institucional é o fato do programa fazer parte da agenda do Governo do Distrito Federal. Caso não houvesse interferência pessoal e direta do Governador e do Secretário da Agricultura em várias etapas críticas na implantação do programa, dificilmente o mesmo teria tido sucesso.

No nível técnico-operacional o sucesso deve-se ao entendimento existente entre os dirigentes das unidades vinculadas e o Secretário, além de seu envolvimento com o programa. Este pré-requisito permitiu à Secretaria constituir o grupo dirigente do programa sem grandes conflitos na tomada de dicisões no desenvolvimento do programa (FZDF, EMATER/DF, SAB, CEASA, DIPOVA).

Constituído o núcleo coordenador estratégico, as ações voltaram-se para articular e negociar com outros setores público e privados envolvidos no programa (BRB, CAESB, 
IEMA, Instituto de Saúde, Carrefour, Shopping Center, Pão de Açúcar, Industriais de Insumos etc.)

\section{Adaptabilidade em Outros Locais}

Já foram implantadas ou estão em fase de implantação nos seguintes municípios: Blumenau, Gaspar, Coronel Freitas, todos em Santa Catarina; Marília, Campos do Jordão, em São Paulo; Mundo Novo em Mato Grosso do Sul.

O PROVE recebeu em visitas técnicas aproximadamente 1.500 pessoas (técnicos, dirigentes, políticos, sindicalistas, pesquisadores etc.) de parios estados/municípios brasileiros e do exterior.

A razão básica da facilidade de implementação do programa em outros municípios/estados é a inexistência de necessidade de recursos para investimento do poder público. Os recursos da agroindústria são financiamentos bancários.

Outra razão é a simplicidade conceitual-técnica-metodológica na elaboração do programa. O desafio está na complexidade e dificuldades “criadas" e também em pequenos detalhes, por exemplo, como produzir etiquetas para os produtos na quantidade de 100/200 por mês.

O maior desafio é colocar em destaque na agenda do Governo, ou seja, a operacionalização exige diversas interferências de peso nas dificuldades criadas (banco, supermercado, Ministério da Saúde, CIF, etc.).

\section{Gênero}

O programa não foi criado para beneficiar especificamente homens e mulheres, e sim, famílias com um todo.

Devido às características culturais do homem do campo voltado mais para atividade de esforço, no caso a lavoura ou atividade de relacionamento comercial (compra de insumos, entrega de produtos, pagamento, etc.) a mulher acabou por assumir, na maioria dos casos, a produção da agroindústria. Talvez o fato da agroindústria ter muito a ver com atividades “doméstica", cozinhar, lavar, picar verdura/frutas, o homem por uma questão cultural, tenha mais resistência a atuar diretamente no beneficiamento, exceção para a agroindústria de lingüiça e defumado, onde o homem exerce papel importante na produção. 


\section{3 - FUNDAMENTAÇÃO TEÓRICA}

\section{CONSIDERAÇÕES SOBRE A MICRO E A PEQUENA EMPRESA}

Para aferir-se a população escolhida para estudo, torna-se necessário tecer alguns comentários acerca da definição e do critério de classificação do que seja uma micro e uma pequena empresa: bem como da importância de sua participação na economia, dos problemas que impedem o crescimento e de possíveis alternativas que venham solucionar esses problemas.

\section{Conceituação das Micro e Pequenas Empresas}

Para SALOMON (1986), existem duas categorias gerais de pequenas empresas:

a) A microempresa, em que o proprietário é o principal operário e tem um determinado número de empregados que trabalham, em geral. como seus assistentes diretos; e

b) A empresa em que o proprietário dirige, de um modo geral, o trabalho de seus empregados.

No entanto, o que se pode perceber concretamente é que a definição, ou a simples conceituação, do que são MPEs tem-se constituído em tarefa relativamente complexa. Basicamente, face a existência dos seguintes fatores:

A presença de um grande número de variáveis, tanto quantitativas quanto qualitativa, tais como: ativo fixo, número de empregados, faturamento, consumo de energia, volume de produção, tipo de participação no mercado. acesso ao crédito, etc.

_A demora na regulamentação do art.179 da Constituição Federal que versa sobre o tratamento diferenciado às MPEs. Este fato levou diversas unidades da Federação a buscarem disciplinar a matéria, adotando, muitas vezes, soluções conflitantes que não lograram a meta de tornar as MPEs estratégia de desenvolvimento econômico autosustentado;

_O fato de a noção de Micro e Pequena Empresas ser uma idéia puramente relativa, admitindo, portanto, mais de um ponto de vista. (MORELLI, 1994:13)

De acordo com o autor, as variáveis qualitativas são aquelas que se referem à forma de administração e ao tipo de inserção no mercado. Dentre elas destacam-se:

- acesso ao mercado de capitais e às inovações tecnológicas; 
- existência de divisão do trabalho especializado;

- nível de especialização da mão-de-obra

- existência de relacionamento pessoal do administrador com empregado/fornecedores;

- relação internas/externas do tipo essencialmente pessoal;

- ausência de um sistema de informação para tomada de decisões;

- a forma e o grau de concorrência;

- tipo de máquinas e ferramentas utilizadas;

- a caracterização da tecnologia adotada (tradicional ou moderna;

- nacional ou estrangeira; capital intensiva ou trabalho intensiva);

- a existência de participação direta do proprietário no processo de produção, comercialização e/ou prestação de serviços e, por fim, a falta de conhecimento/utilização de modernas técnicas de administração.

Por outro lado. as variáveis quantitativas são aquelas baseadas em informações colhidas no registro contábil das empresas e nos censos econômicos, quais sejam:

- volume de emprego;

- volume de produção;

- investimento realizado (ativo fixo);

- faturamento;

- potência instalada;

- produtividade;

- capital social;

- patrimônio líquido;

- participação no respectivo mercado.

Apesar do grande número de variáveis, torna-se difícil conceituar as MPEs, haja vista que, se formos utilizar as variáveis qualitativas, o principal obstáculo é a dificuldade de sua efetiva constatação devido ao fato de que essas variáveis, em sua maioria, baseiam-se em conceitos "vagos" de difícil mensuração. Por outro lado, se utilizarmos as variáveis quantitativas, os principais problemas residem, justamente na não existência de um sistema contábil organizado nas MPEs e a pouca confiabilidade de alguns dados obtidos nos levantamentos, principalmente nos censos econômicos.

Nota-se que no Brasil, não existe unanimidade ou homogeneização de conceitos, de critérios ou de definições do que seja uma micro ou uma pequena empresa. Então, 
levando-se em consideração essas colocações feitas anteriormente, sobre as grandes dificuldades de se chegar a um consenso sobre a definição de micro e pequena empresa, resolveu-se optar pelas pelas variáveis "receita bruta", que é a variável utilizada pelo governo federal, estadual e municipal e "número de pessoal ocupado", que é utilizada pelo Serviço Nacional de Apoio às Micros e Pequenas Empresas - SEBRAE.

Convém lembrar que tanto o SEBRAE como os censos econômicos do Instituto Brasileiro de Geografia e Estatística - IBGE, consideram como pessoas ocupadas, aquelas que recebem remuneração independentemente de ter ou não vinculo empregatício.

SANTANA (1994:34), na Série O Empreendedor - Edição SEBRAE, afirma que "De acordo com o Estatuto da Microempresa (Lei $\mathrm{n}^{0}$ 7.256, de 27.11.1984), com as alterações introduzidas pela (Lei $\mathrm{n}^{\circ} 8.383$ de 30.12.1991), são microempresas aquelas cujo faturamento anual não ultrapassa o valor de 96.000 UFIR - Unidade Fiscal de Referência”.

Continuando, o autor acrescenta que, "O SEBRAE adota, em relação às microempresas, o critério do Estatuto e, com relação às demais empresas, classifica-as pelo número de empregados". Veja quadro 1.

\section{Quadro 1}

Classificação das Empresas quanto ao Porte, de acordo com o n ${ }^{\circ}$ de Empregados.

\begin{tabular}{c|c|c}
\hline CLASSIFICAÇÃO & \multicolumn{2}{|c}{ NÚMERO DE EMPREGADOS } \\
(Porte) & Indústria & Comércio/Serviços \\
Pequena Empresa & 20 a 99 & 10 a 49 \\
Média Empresa & 100 a 499 & 50 a 99 \\
Grande Empresa & acima de 500 & acima de 100 \\
\hline
\end{tabular}

Fonte: SEBRAE - SÉRIE O EMPREENDEDOR, Vol. 1.

Convém ressaltar que apesar do autor acima citado afirmar que o SEBRAE classifica a microempresa de acordo com o Estatuto da Microempresa, o Jornal "Folha de São Paulo" publicou, em 3 de julho de 1994, em encarte do SEBRAE - SEU NEGÓCIO NA NOVA ERA - onde lê-se "ENTENDA O “TAMANHO” DAS EMPRESAS. Veja quadro 2. 


\section{Quadro 2}

Classificação das Empresas quanto ao Porte, de acordo com o Número de funcionários.

\begin{tabular}{c|c|c|c|c}
\hline \multicolumn{5}{c}{$\begin{array}{c}\text { ENTENDA O “TAMANHO” DAS EMPRESAS } \\
\text { Classificação por n }{ }^{\circ} \text { de funcionários }\end{array}$} \\
\hline SETOR & $\begin{array}{c}\text { MICROEMPRESA } \\
(\mathrm{ME})\end{array}$ & $\begin{array}{c}\text { PEQUENA } \\
\text { EMPRESA (PE) }\end{array}$ & $\begin{array}{c}\text { MÉDIA EMPRESA } \\
(\mathrm{MDE})\end{array}$ & $\begin{array}{c}\text { GRANDE EMPRESA } \\
(\mathrm{GE})\end{array}$ \\
\hline Industrial & Até 19 & 20 a 99 & 100 a 499 & Acima de 500 \\
\hline Com. / Serviços & Até 09 & 10 a 49 & 50 a 99 & Acima de 100 \\
\hline
\end{tabular}

Fonte: SEBRAE - SÉRIE SEU NEGÓCIO NA NOVA ERA.

Sabe-se que quase todas as necessidades são satisfeitas através de empresas. Más, o que é uma empresa? Conforme CHIAVENATO(1995:3), “empresa é um conjunto de pessoas que trabalham juntas, no sentido de alcançar objetivos por meio da gestão de recursos humanos, materiais e financeiros". Assim, as pessoas atingem objetivos que isoladamente seria impossível alcançar. Esses objetivos podem ser classificados em diretos e indiretos. Os diretos referem-se geralmente à produção ou venda de mercadorias ou à prestação de serviços; os indiretos referem-se ao lucro, ao atendimento das necessidades do cliente e às finalidades sociais. Conseqüentemente, jamais irá existir empresa sem que haja pessoas, recursos e objetos a serem alcançados.

Segundo CHIAVENATO (1995:8), a microempresa tem suas vantagens. Além da isenção do Imposto de Renda para o faturamento anual de até 96.000 UFIR, está dispensada da escrituração dos livros fiscais, desde que sejam conservados documentos e papeis relativos aos negócios realizados; não há necessidade de se manter um contador, assim a contabilidade poderá ser feita dentro da empresa ou por um escritório externo, desde que mantidos os demonstrativos contábeis.

O autor acrescenta ainda que,

"Anualmente as micros têm de apresentar declaração de imposto de renda de pessoa jurídica, declaração de microempresa para a Secretaria Estadual da Fazenda, declaração de microempresa para a Prefeitura e escrituração dos livros. Mensalmente, as micros devem recolher a contribuição ao INSS de seus empregados, a parcela do empregador, o FGTS, o DARF de imposto de renda retido nos pagamentos dos empregados e/ou salários e a contribuição da empresa ao INSS. Além disso, todas as obrigações trabalhistas devem ser recolhidas periodicamente. Devem ser mantidos na empresa os livros de registro de 
empregados, cuja abertura deve ser registrada no Ministério do Trabalho, as folhas de pagamento e os recibos dos empregados, a ficha do salário-família e o termo anual de responsabilidade, a ficha de auxílio maternidade, as guias de recolhimento de impostos, taxas e contribuições (como FGTS, INSS), todos os documentos dos sócios da empresa, bem como as notas fiscais". (CHIAVENATO, 1995:8-9)

\section{Quadro 3}

Faturamento Anual para uma Empresa ser Micro.

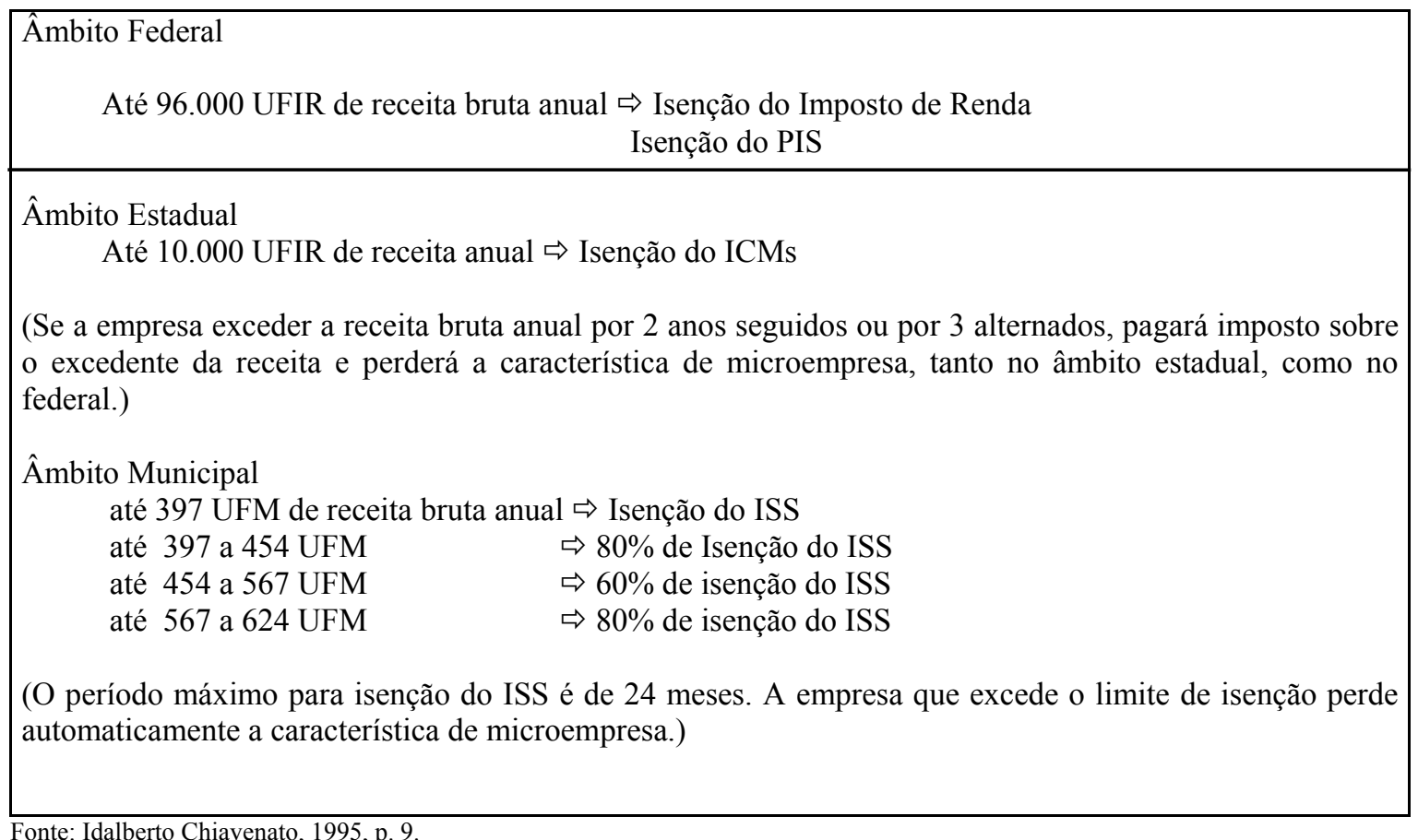

Conforme foi abordado anteriormente, na visão de MORELLI (1994), SANTANA (1994) e CHIAVENATO (1995), até então, não havia um consenso sobre a definição de micro e pequena empresa: vários critérios eram utilizados para classificá-las, entre eles "renda bruta" e "número de empregados".

Entretanto, segundo SILVA (1997:6), foram fixados para enquadramento das microempresas (ME) e empresas de pequeno porte (EPP), conforme artigo $2^{\circ}$ da Lei 9.317/96, publicada no Diário Oficial em 06/12/96, a qual entrou em vigor em 1\%01/97. Considera-se:

"I - microempresa, a pessoa jurídica que tenha auferido, no ano-calendário, receita bruta igual ou inferior a R \$120.000,00 (cento e vinte mil reais)"; 
"II - Empresa de pequeno porte, a pessoa jurídica que tenha auferido, no ano-calendário, receita bruta superior a $\mathrm{R} \$ 120.000,00$ (cento e vinte mil reais) e igual ou inferior a $\mathrm{R} \$$ $720.000,00$ (setecentos e vinte mil reais)".

$\mathrm{O}$ autor acrescenta que, caso a empresa inicie as atividades no próprio ano-calendário, os limites anuais de receita serão proporcionais ao número de meses em que a pessoa jurídica houver exercido atividade, desconsideradas as frações de meses.

Assim, cabe aplicar o seguinte quadro:

\section{Quadro 4}

Verificação do Enquadramento no Limite de Receita Anual para as ME e EPP.

\begin{tabular}{c|c|c}
\hline $\begin{array}{c}\text { N}^{\mathrm{o}} \text { DE MESES DE } \\
\text { ATIVIDADES }\end{array}$ & $\begin{array}{c}\text { LIMITE DE RECEITA } \\
\text { PARA ME }\end{array}$ & $\begin{array}{c}\text { LIMITE DE RECEITA } \\
\text { PARA EPP }\end{array}$ \\
\hline 1 & $10.000,00$ & $60.000,00$ \\
3 & $20.000,00$ & $120.000,00$ \\
4 & $30.000,00$ & $180.000,00$ \\
5 & $40.000,00$ & $240.000,00$ \\
6 & $50.000,00$ & $300.000,00$ \\
7 & $60.000,00$ & $360.000,00$ \\
8 & $70.000,00$ & $420.000,00$ \\
9 & $80.000,00$ & $480.000,00$ \\
10 & $90.000,00$ & $540.000,00$ \\
11 & $100.000,00$ & $600.000,00$ \\
12 & $110.000,00$ & $660.000,00$ \\
\hline
\end{tabular}

Fonte: Guia IOB de Contabilidade. Suplemento Especial, 1997, p. 7

\section{Importância da Participação das MPEs na Economia do País}

Sabe-se que, independentemente do nível de desenvolvimento de qualquer país, as MPEs têm uma substancial importância em seu processo evolutivo, contribuindo significativa para este, quer seja do ponto de vista econômico, quer seja do ponto de vista social, ou do ponto de vista político.

Para melhor e maior esclarecimento da importância da participação das MPEs na economia brasileira, veja quadros 5,6 e 7 . 


\section{Quadro 5}

BRASIL - Participação dos estabelecimentos segundo o Porte por Setor. (\%)

\begin{tabular}{l|c|c|c|c|c|c}
\hline \multicolumn{1}{c|}{ Setor } & Composição & \multicolumn{5}{c}{ Porte do Estabelecimento } \\
\hline & & ME & PE & MDE & GE & Sem Declaração (1) \\
\hline Indústria & 15,0 & 74,91 & 12,57 & 4.07 & 0,54 & 7,91 \\
Comércio & 52,5 & 90,92 & 7,79 & 0,56 & 0,27 & 0,46 \\
Serviços & 32,5 & 93,54 & 5,44 & 0,48 & 0,44 & 0,10 \\
\hline
\end{tabular}

(1) Inclui empresas sem declaração de pessoal ocupado e unidades de apoio indireto à produção.

Fonte: SEBRAE/Nacional - Calculado com base nos Censos Econômicos do IBGE, 1990.

De acordo com o quadro 5, constata-se que as MPEs estão concentradas, em sua maioria, no comércio, 98,71\%, e na prestação de serviços, 99,98\%; já no setor industrial a participação das MPEs é menor, 87,48\%. Entretanto, somando-se 87,48\% a 7,91\% esse número fica em torno de $95 \%$. Assim, fica evidente que os setores preferidos das MPEs brasileiras são comércio e serviços.

\section{Quadro 6}

BRASIL - Participação dos Estabelecimentos no Total da Receita/Valor Bruto da Produção Industrial, Comercial e dos Serviços. (\%)

\begin{tabular}{l|c|c|c|c|c|c}
\hline \multicolumn{1}{c|}{ Setor } & Composição & \multicolumn{5}{c}{ Porte do Estabelecimento } \\
\hline & & ME & PE & MDE & GE & Total (1) \\
\hline Indústria (2) & 57,4 & 5,77 & 17,29 & 41,90 & 33,09 & 98,01 \\
Comércio (3) & 37,2 & 29,58 & 42,62 & 12,48 & 14,78 & 99.46 \\
Serviços (3) & 5,4 & 34,36 & 22,12 & 9,86 & 33,22 & 99,56 \\
\hline Total & 100 & 16,11 & 26,96 & 29,23 & 26,25 & 98,99 \\
\hline
\end{tabular}

(1) inclui empresas sem a declaração de pessoal ocupado

(2) valor bruto de produção industrial

(3) receita

Fonte: SEBRAE, Síntese dos principais indicadores relativos a participação das MPEs na economia brasileira. Brasília. Nov. 1991.

Observando-se o quadro 6, percebe-se que as MPEs são responsáveis por $72,2 \%$ da receita do comércio, $56,48 \%$ dos serviços e $23,06 \%$ do valor bruto da produção brasileira. Concluindo, as MPEs participam com 43,07\% da receita/valor bruto da produção dos três setores.

OBS: Para o setor comércio e serviços usou-se a variável receita e para a indústria, a variável valor bruto da produção - VBP (montante de produção gerada nos estabelecimentos industriais). 


\section{Quadro 7}

BRASIL - Participação dos Estabelecimentos na oferta de emprego nos setores. (\%)

\begin{tabular}{l|c|c|c|c|c|c}
\hline \multicolumn{1}{c|}{ Setor } & Composição & \multicolumn{5}{c}{ Porte do Estabelecimento } \\
\hline & & ME & PE & MDE & GE & Total (1) \\
\hline Indústria & 57,4 & 5,77 & 17,29 & 41,90 & 33,09 & 98,01 \\
Comércio & 37,2 & 29,58 & 42,62 & 12,48 & 14,78 & 99.46 \\
Serviços & 5,4 & 34,36 & 22,12 & 9,86 & 33,22 & 99,56 \\
\hline Total & 100 & 16,11 & 26,96 & 29,23 & 26,25 & 98,99 \\
\hline
\end{tabular}

(1) não inclui pessoal de apoio indireto a produção

Fonte: SEBRAE. Op. cit.

Conforme o quadro 7, observa-se que as MPEs são responsáveis por 59,38\% do total da mão-de-obra empregada nos três setores. Assim, nota-se que, no setor comercial, que corresponde a 33\% do total de mão-de-obra empregada nos três setores, as MPEs respondem por $80,25 \%$ do emprego; nos serviços, que correspondem a $23 \%$ do total de mão-de-obra empregada, as MPEs empregam 63,58\% do pessoal ocupado e na indústria, que representa os $44 \%$, as MPEs respondem por $41,57 \%$ do emprego.

A importância das MPEs, no Brasil, não se restringe apenas ao número de estabelecimento, receita gerada e número de empregos criados. Existe uma série de outros fatores que tornam as MPEs peça fundamental em qualquer política econômica que busque maximizar o crescimento e torná-lo menos desigual.

\section{Principais Fatores Limitantes do Crescimento das MPEs}

São vários os fatores que limitam o crescimento das MPEs. O conteúdo desses fatores pode variar em função das diferentes regiões do país, que apresentem características econômico-sociais distintas; e classificam-se em internos e externos.

a) Fatores Internos - "São aqueles passíveis de solução pelo empresário individual, estando a sua abrangência mais diretamente relacionada à gestão da empresa".

(MORELLI, 1994:39).

Esses fatores, portanto, estão relacionados a Administração da Empresa. Dentre eles, evidencia-se a falta de :

- práticas de planejamento de produção;

- levantamento de custos;

- controle de estoques;

- prática de planejamento de vendas; 
- controle de qualidade;

- emprego de métodos de avaliação de produtividade;

- utilização de "layout" planejado;

- treinamento de recursos humanos;

- utilização de recursos de informática.

b) Fatores Externos - "São aqueles que dependem de medidas mais gerais, até mesmo de política econômica para a sua solução, superando, portanto, os limites da firma individual e abrangendo todo um setor ou uma região ou, ainda, um país".

(MORELLI, 1994:39)

Conforme o autor, dentre esses fatores, destacam-se:

- industrialização tardia;

- acesso ao crédito;

- investimentos tecnológicos;

- compras governamentais;

- acesso às fontes de informações;

- transferência de mais-valia;

- obrigações tributárias e jurídicas;

- qualificação de mão-de-obra.

\section{Possíveis Alternativas para o Crescimento das MPEs}

Após o exposto, percebe-se que são inúmeros os problemas enfrentados pelas MPEs. MORELLI (1994:46), sugere possíveis alternativas de solução para esses problemas, quais sejam:

- implantação de Redes de Informações;

- programa de capacitação;

- desburocratização do crédito;

- consultoria tecnológica;

- racionalização e descentralização das compras governamentais ;

- conscientização e participação na elaboração das políticas econômicas. 


\section{CONSIDERAÇÕES SOBRE O EMPREENDEDOR}

\section{Conceituação de Empreendedor}

$\mathrm{Na}$ visão de ANSOFF(1981), “o empreendedor é aquele indivíduo cujo desejo de independência foi capaz de motivá-lo no sentido de estabelecer sua própria empresa". Conforme o autor, é comum os empreendedores iniciarem uma nova atividade, frente a resultados negativos ligados à experiências empresariais do passado. Continuando, destaca alguns dos elementos, que causam essa saída da organização:

a) desequilíbrio entre as contribuições inovadoras importantes e recompensa a eles devida;

b) falta de reconhecimento pela contribuição inovadora nas políticas de promoção e salário;

c) comunicação empresarial inadequada desde a geração de uma idéia até seu aproveitamento final;

d) ingerência da burocracia empresarial nas necessidades de realização pessoal.

Além dos elementos acima citados, considerados internos às empresas, há, também, segundo o autor, os considerados externos às empresas, que alimentam o ânimo do empreendedor. Eis alguns deles:

a) desejo de realizar o seu próprio negócio;

b) motivação para ser seu próprio patrão;

c) desejo de prestígio pessoal;

d) desejo de riqueza;

e) desejo de realização pessoal ou satisfação pura e simples de vencer.

Talvez o primeiro grande teórico que se preocupou em estudar a importância do empreendedor foi SCHUMPETER (1982). Denominando-o de empresário, este autor caracterizou-o como "o indivíduo que consegue levar a cabo novas combinações, e perde seu caráter assim que tiver montado seu próprio negócio, quando dedica-se a dirigi-lo, como outras pessoas dirigem seus negócios". De acordo com a teoria Schumpeteriana, o empreendedor possuiria três características básicas, a saber:

- Sonho ou desejo de fundar um reino privado (até mesmo uma dinastia);

- Desejo de conquistar, ou seja, impulso para lutar, para provar-se superior aos outros, de ter sucesso não de seus frutos, mas do próprio sucesso;

- Alegria de criar, de fazer coisas ou executar a energia e a engenhosidade. 
Segundo LEAL e VOLKEMA (1988), o economista escocês Adam Smith (1723-1790) foi um dos primeiros a caracterizar o empreendedor. Smith atribuiu-lhe o papel de criador de riquezas, mas não distinguiu claramente as figuras do empreendedor e do capitalista.

Na visão de DEGEN (1989), ser empreendedor significa “ ter acima de tudo, a necessidade de realizar coisas novas, pôr em prática idéias próprias, característica de personalidade e comportamento". Aponta, ainda, três motivos básicos que seriam os responsáveis pela atividade empreendedora, a saber:

a) Vontade de ganhar dinheiro;

b) Desejo de sair da rotina;

c) Vontade de ser seu próprio patrão.

Para RESNIK (1990), “Os empreendedores fazem as coisas acontecerem e conseguem resultado. Transformam idéias novas ou inovadoras em operações comerciais reais". A seguir, enfatiza: "Mas nem todos os empreendedores têm conhecimento ou disposição para administrar uma empresa em atividade, fazendo com que as coisas certas aconteçam e obtendo os resultados corretos". Para ele, os empreendedores são "preeminentemente iniciadores" e, geralmente não estão atentos às responsabilidades administrativas ou se chateiam com elas.

Diferente da opinião de SCHUMPETER, DRUCKER (1991), vê o empreendedor como aquele que "pratica a inovação sistematicamente". DRUCKER acredita que a prática de inovar pode ser aprendida. Empreendimento para ele não é nem arte nem ciência, é uma prática. O inventor é tomado como o empreendedor. Para ele isso não é verdade. É a inovação que caracteriza o empreendimento. A visão deste autor aproxima-se do significado da palavra "empreendedor" : o que pratica, tenta uma empreitada laboriosa e difícil, põe em execução. 
No que se refere à inovação, DRUCKER (1992:224), diz que :

"Quando o economista francês J. B. Say cunhou a expressão entrepeneur há 200 anos, ele quis criar um manifesto e uma declaração de intenções : em seu esquema, o empreendedor era alguém que perturba e desorganiza. Mais tarde Joseph Schumpeter,o único economista moderno a levar a sério o caráter empreendedor, descreveu o processo como "destruição criativa". Para conseguir o novo e melhor, você tem que jogar fora o velho, cansado, obsoleto, não mais produtivo, assim como os erros, fracassos e más orientações dos esforços do passado..."

A inovação sistemática "consiste na busca, intencional e organizada, de mudanças, e na análise sistemática das oportunidades que tais mudanças poderiam oferecer para inovações econômicas ou sociais". (DRUCKER, 1992:226) Assim, o empreendedor, para ele, é aquele que inova, mas para inovar é preciso praticar o "abandono organizado", o que é muito difícil, uma vez que a maioria das organizações desenvolvem uma forte ligação emocional aos produtos. Acrescenta, ainda, que "A chave para a inovação é sentar-se a cada três anos e colocar em julgamento pela vida todos os aspectos da empresa : cada produto, serviço, tecnologia, mercado e canal de distribuição".

Segundo AZEVEDO (1992) o empreendedor é, sobretudo, "aquele indivíduo que tem necessidade e é capaz de desenvolver novos projetos, o empreendedor que assume a responsabilidade de conduzir um negócio próprio, de tal forma que esse empreendimento funcione e alcance o sucesso". O autor contradiz a visão de Schumpeter, quando se refere à condução do próprio negócio.

TORRES (1995:37), reporta-se ao empreendedor, enfatizando que,

"Muitos autores tem, freqüentemente, colocado o termo "empreendedor" como sinônimo de "empresário", o que não é verdade, pois, para muitos, o empreendedor se confunde na figura do empresário, dificultando, deste modo, o entendimento sobre o assunto".

Neste contexto, AQUINO (1986) em sua obra "HISTÓRIA EMPRESARIAL VIVIDA", expõe depoimentos de vários empresários brasileiros bem sucedidos que expressam suas opiniões sobre a diferença entre o empreendedor e o empresário. Dentre eles, destaca:

- Jorge Gerdau Johannpeter, declarou a AQUINO que, a atitude do empreendedor, no ato pioneiro, quase intuitivo, de lançar-se a algum empreendimento, nem sempre significa que tenha todas as características exigidas, hoje, do moderno empresário, que se resumem numa extraordinária capacidade de tratar, de levar ao mercado um produto de qualidade $\mathrm{e}$ custo satisfatório. Nem todo empreendedor tem, necessariamente, características de 
empresário. No entanto, o empresário, para ter sucesso precisa de uma cota de empreendedor para garantir a sobrevivência plena de sua empresa.

- Ângelo Calmon de Sá, declarou a AQUINO que, o empreendedor, como a própria palavra o diz é aquele que empreende alguma coisa, que inicia (...), o que faz um negócio novo, o que se dedica a construir, a realizar alguma coisa, seja uma máquina, um produto, uma invenção, ou outro tipo de projeto que ele empreende. O empresário, como a palavra o diz, é um homem que, no fundo, administra, gerência uma empresa e faz com que ela progrida (...), é aquele que chega após o empreendimento existir, administra e faz com que esse empreendimento prospere e continue.

- Márcio Fontes relatou a AQUINO que, o empreendedor e aquele que vive cada momento o objetivo prático de sua ação. Consegue equacionar os problemas de modo correto para que os resultados apareçam com data visível, números claros e perfeitamente definidos. O empresário é alguém que zela mais pela instituição do que pelo objetivo do trabalho (...) é um indivíduo que tem a visão de dar continuidade à sua obra, que estará viva além de sua própria vida física, que qualquer coisa que plante; dela colherá. Mas, não necessariamente sob a forma de lucros, de resultados contábeis ou mesmo em tempo curto, visível e determinado.

- Eugênio Staub, também expôs a AQUINO que, um empreendedor é sempre um empresário em potencial. Um empreendedor possui características que o situam como um dos principais agentes do sistema econômico que valoriza a iniciativa privada. Um empreendedor é aquele indivíduo que assume um papel ativo em termos do agente econômico. Toma iniciativa, assume riscos e dá partida ao seu projeto: o empreendimento. Um empreendedor é, iqualmente, o indivíduo que trabalha bem acima da média e se gratifica muito com os resultados positivos, sejam materiais ou subjetivos, de sua obra (...). O empresário é um empreendedor em outra escala e com diferentes desafios e perspectivas. Para Staub, todo empresário é, necessariamente, um empreendedor, mas todo empreendedor não é, necessariamente, um empresário.

Em síntese, para AQUINO (1997)

"O empreendedor (pioneiro, criador de novos negócios) começa a ter o seu papel sufocado quando sua obra empresarial (empresa ou grupo de empresas) cresce acima de suas possibilidades e ele não teve a iniciativa (ou condições) de dotar seus empreendimentos de uma estrutura organizacional e gerência no sentido de ter o seu talento criativo e de 
realização ampliado e, acima de tudo, de ver sua obra consolidada e bem sucedida ao longo de sua vida, principalmente depois de sua morte".

O empresário é, também, um criador de empresa, porém é mais raro o empreendedor ser um empresário. A não ser quando ele, o empreendedor consegue romper suas limitações de meio fazedor de negócios; o empresário tem, portanto, características de pioneiro, de empreendedor, apesar de haver bem-sucedidos empresários que não criaram empresas, residindo seus méritos em administrar com competência a obra herdada por seus antepassados. O empresário entretanto tem outras características, usualmente não existentes no proprietário-empreendedor. Uma delas é que ele (o empresário) "cresce" tanto no plano individual (como pessoa, como indivíduo, como ser humano), quanto no empresarial, cumprindo obrigações ao nível de nobre missão empresarial, investindo a realizando projetos, criando riquezas, dando empregos, contribuindo para o desenvolvimento do país no qual ele opera e lucra".

\section{INTRAPRENEUR/ENTREPRENEUR}

O termo "ENTREPRENEUR" é derivado da palavra francesa entreprende = empreendedor.

PINCHOT III (1989), em sua obra "INTRAPRENEURING” (um bestseller internacional), define:

"ENTRAPRENEUR: Todos os "sonhadores que realizam". Aqueles que assumem a responsabilidade pela criação de inovações de qualquer espécie dentro de uma organização. O intrapreneur pode ser o criador ou o inventor, mas é sempre o sonhador que concebe como transformar uma idéia em uma realidade lucrativa.

"INTRAPRENEUR: O empreendedor que desempenha o papel de um intrapreneur fora de uma organização."

O autor, prefaciando a referida obra, acrescenta alguns conceitos, definições e características, referentes aos termos "intrapreneurs" e "entrepreneurs", onde percebe-se com clareza a diferença entre eles, quais sejam:

\section{Intrapreneurs ( Conceito/Definição/Características)}

- aqueles que assumem a responsabilidade pela criação e inovação de qualquer espécie, dentro de uma organização;

- poder ser o criador ou o interventor, mas é sempre o sonhador que concebe como transformar uma idéia em uma realidade lucrativa; 
- são homens e mulheres que a partir de uma idéia, e recebendo a liberdade, incentivo e recursos da empresa em que trabalham, dedicam-se entusiasticamente para transformá-la em um produto bem-sucedido;

- ser um "intrapreneur" é, de fato, um estado de espírito (...), não necessariamente não estabelecido na infância; ele pode ser desenvolvido em qualquer ponto de vista, dados o desejo e a oportunidade;

- são os integradores que combinam os talentos dos técnicos e dos elementos de marketing, estabelecendo novos produtos, processos e serviços;

- empreendedor interno;

- falta de disposição para aceitar um não como resposta;

- em alguns círculos empresariais, os visionários são desprezados como sendo sonhadores não práticos;

- têm pouca satisfação em aderir a padrões impostos por outros e podem ignorálos;

- são famosos em negligenciar a documentação;

- estabelecem para si mesmos padrões internos muito elevados, nas áreas que consideram importantes;

- luta constante pela excelência, combinada com uma boa dose de impaciência;

- a falta de respeito pela tradição;

- novos produtos e serviços de qualidade superior, em prazos quase irreais.

- a importância dos "intrapreneurs" fica mais evidente depois que eles saem da organização.

\section{Intrapreneurismo: “é um sistema revolucionário para acelerar as inovações dentro}

de grandes empresas, através de um uso melhor dos seus talentos entrepreneurs."

Intrapreneurs (Corporativos de Sucesso)

- não dispõem de capital próprio para iniciar novos empreendimentos;

- devem começar do zero, persuadindo a gerência de que suas novas idéias são promissoras;

- não são livres para orientar seus próximos empreendimentos por seus próprios critérios intuitivos;

- têm que justificar cada movimento;

- dificuldades para assumir uma visão de longo prazo - nunca sabem se seus projetos serão sacrificados por algum capricho;

- impossibilidade de usarem os ganhos de um sucesso para financiar o seguinte;

- a não delegação de poder aos "intrapreneurs" de sucesso impede que as organizações se beneficiem com seus inovadores experimentados, que as abandonam ou se tornam ineficazes; 
- o sucesso como "intrapreneurs" lhe dá a experiência e as pistas para ser mais facilmente bem-sucedido como "entrapreneur";

- a importância dos "intrapreneurs" fica mais evidente depois que eles saem da organização.

\section{Intrapreneurs (Independentes)}

- são primordialmente motivados a satisfazer uma necessidade pessoal de realização;

- a principal meta para a maior parte deles não é a aquisição de grandes riquezas pessoais;

- a maioria deixa as corporações não porque considera insuficientes seus salários e benefícios, mas porque se sente frustada em suas tentativas de inovar;

- ganham liberdade de ação;

- dispõem de capital próprio;

- o capital ganho nos empreendimentos dá aos "entrapreneurs";

○ o poder de assumir riscos;

- de adotar prazos maiores para testar novas idéias;

○ pagar por seus próprios erros sem ter de justificá-los para um chefe.

○ são livres para orientar seus próximos empreendimentos por seus próprios critérios intuitivos.

Em suma, o autor mostra que o termo "intrapreneur" (empreendedor interno) é usado para designar a pessoa que tem espírito empreendedor, mas ao invés de manter um negócio próprio para viabilizar suas idéias, usa a estrutura da empresa onde trabalha. No que se refere ao termo "entrepreneur" (empreendedor externo), é aquele indivíduo que parte para montar seu próprio negócio e, se bem-sucedido, torna-se, um “entrepreneur independente".

\section{TIPOS DE EMPREENDEDORES}

SMITH, citado por VRIES [199-], sugere dois tipos de empreendedores: o empreendedorartesão e o empreendedor-oportunista.

\section{O Empreendedor-Artesão}

- indivíduo limitado em educação e treinamento;

- pouca preocupação e envolvimento sociais;

- lacuna no que tange a competência de lidar com o ambiente social; 
- orientação de tempo limitada e restrita.

\section{O Empreendedor-Oportunista}

- exibe amplo treinamento e educação;

- grande preocupação e envolvimento sociais;

- grande confiança em lidar com o ambiente social;

- preocupação e orientação em direito ao futuro.

Desta forma, o empreendedor-artesão, tenderá para a construção de uma firma rígida; enquanto que o empreendedor-oportunista, criará uma firma adaptativa.

O autor acrescenta que, "Existe a possibilidade de que um novo tipo de empreendedor esteja surgindo: um indivíduo mais bem educado, não tão impulsivo, menos preocupado com o controle e independência e mais adaptativo em sua abordagem com o meio ambiente."

\section{O EMPREENDEDOR, O GERENTE E O TÉCNICO}

Para se tornar um empresário de sucesso, o indivíduo precisa reunir a imaginação e a determinação de um empreendedor, a habilidade e capacidade de organizar de um gerente e os conhecimentos de um técnico. É verdade que conflitos sempre existirão entre esses tipos de personalidade mas precisam ser superados para que haja harmonia e daí resulte o bom funcionamento do empreendimento.

GERBER (1992:22-4), aponta características distintas para cada uma destas personalidades, onde a situação ideal é a de equilíbrio entre as três qualificações, é o "famoso três-em-um", quais sejam:

\section{O Empreendedor:}

- transforma a condição mais insignificante numa excepcional oportunidade;

- é o visionário dentro de nós;

- o sonhador;

- a energia por trás de toda atividade humana;

- a imaginação que acende o fogo do futuro;

- o catalisador das mudanças;

- vive no futuro, nunca no passado, raramente no presente; 
- é o inovador, o grande estrategista, o criador de novos métodos para penetrar ou criar novos mercados, o gigante dominador do mundo;

- é a personalidade criativa;

- lida melhor com o desconhecido, perscrutando o futuro, transformando possibilidades em probabilidades, caos em harmonia;

- cria muita confusão à sua volta, previsivelmente perturbadora para as pessoas que o ajudam em seus projetos;

- para o empreendedor, o "homem comum" é sempre um problema que tende a obstruir o sonho.

\section{O Gerente:}

- a personalidade gerencial é programática - sem o gerente não haveria planejamento, nem ordem, tampouco previsibilidade;

- vive no passado;

- se agarra de forma compulsiva ao "status quo";

- infalivelmente vê os problemas;

- constrói um casa e vive nela, para sempre;

- cria fileira bem-arrumadas de objetos;

- fica correndo atrás do empreendedor para endireitar a confusão;

- sem o gerente não poderia haver uma empresa, uma sociedade; sem o empreendedor não haveria qualquer inovação, pois é da tensão entre a visão do empreendedor e o pragmatismo do gerente que nasce a síntese da qual surgem todas as grandes obras.

\section{O Técnico:}

- é o executor;

- vive no presente;

- adora o palpável, e o fato de que as coisas podem ser feitas;

- fica felicíssimo quando ele mesmo pode controlar o ritmo de trabalho;

- pensar é, para o técnico uma ocupação improdutiva, a não ser que se trate de algo para o trabalho ser executado;

- é um individualista resoluto;

- todo mundo atrapalha o técnico;

- para o técnico o "sistema" é desumano, frio, asséptico e impessoal.

O autor acrescenta ainda, que:

"Para o gerente, o técnico transforma-se num problema a ser administrado. Para o técnico, o gerente passa a ser um instrumento a ser 
evitado. Para ambos o empreendedor é aquele que causou toda a confusão em primeiro lugar! (...) A verdade é que todos nós temos um empreendedor, um gerente e um técnico dentro de nós. Se estivessem bem equilibrados entre si, estaríamos descrevendo uma pessoa muitíssimo competente."

(GERBER, 1992:25)

\section{OS PADRÕES DE COMPORTAMENTO EMPREENDEDOR}

Conforme VRIES [199-], vários estudos empíricos foram feitos sobre a personalidade empreendedora, muito embora, a maior parte desses estudos não se caracterizam por possuir clareza conceitual, no entanto, é possível fazer algumas generalizações. Para ele, a maior contribuição sobre os padrões de comportamento empreendedor, foi apresentada por McClelland, mas também cita outros estudiosos que se destacaram, dentre eles:

McCLELLAND $\Rightarrow$ (utilizando Testes de Percepção Temática e jogos específicos de habilidade), descobriu que os empreendedores possuem um alto escore na necessidade de realização; e mais recente, mudou a ênfase da realização para a ênfase no poder (argumentando que, para a eficácia da organização, a motivação do poder é requerida), destaca como padrões de comportamento empreendedor, a saber:

- Necessidade de realização

○ os empreendedores possuem um escore alto de realização;

○ tem o desejo de ter responsabilidade pessoal nas decisões;

○ preferem decisões com grau de risco moderado;

○ estão interessados no conhecimento concreto dos resultados das decisões;

○ não gostam de trabalho repetitivo, rotineiro.

- Ênfase no Poder

- Uma grande necessidade de poder combina com um auto controle (poder socializado) em oposição a uma grande necessidade de poder e um baixo auto controle (poder pessoal) resulta em uma grande efetividade organizacional, particularmente se a necessidade de associação também for baixa;

○ O homem com poder pessoal caracterizado pelo "padrão de motivação do conquistador" assemelha-se ao empreendedor e representa aqueles indivíduos que são difíceis de se organizarem em qualquer sistema. Sua falta de inibição ou de auto controle limita sua efetividade como construtores de grandes instituições apesar de seu sucesso em inspirar as pessoas no estágio inicial de crescimento da organização. 
COLLINS E MOORE $\Rightarrow$ (sem a ênfase na necessidade de realização e poder):

- os empreendedores sofrem a falta de problemas de resolução (para usar as suas palavras): "Apesar de ficar em pânico com a idéia do sucesso ou do sucesso excessivo";

- preferem ter relações patriarcais com seus subordinados;

- sentem-se desconfortáveis com figuras autoritárias (grande necessidade de autonomia);

- possuem um alto grau de ansiedade e destruição.

SCHARAGE $\Rightarrow$ (influenciado pelos estudos McCLELLAND e COLLINS e MOORE):

- uma pessoa com grande necessidade de realização, com baixa motivação de poder e ciente de si mesmo, do mercado e dos empregados.

ROBERTS, WAINE e RUBIN $\Rightarrow$ (questionam as descobertas de SCHRAGE):

- as companhias com maiores performances são conduzidas por empreendedores com grande necessidade de realização e uma necessidade de poder moderado;

- os empreendedores com necessidades de realização e poder altas tinham um desempenho inferior.

LYNN $\Rightarrow$ (depois de aplicar em um grupo de empreendedores o "Inventário de Personalidade" de EYSENCK):

- os empreendedores possuem um alto escore de neuroticismo (ansiedade) se comparados com um grupo de gerentes comuns

KOMIVES $\Rightarrow$ (valores dos empreendedores de alta tecnologia) :

- um grande senso estético diferenciando os empreendedores da população em geral;

- possuem um escore elevado de orientação técnica e baixo nos valores religiosos;

- possuem uma elevada realização, orientação de liderança e decisão mas uma baixa orientação de metas, necessidades de suporte, regularidade, conformidade e mentalidade prática;

- não possuem altos escores em valores econômicos.

LITVAK e MAULE $\Rightarrow$ (pesquisaram empreendedores técnicos no Canadá):

- desejam possuir seu próprio negócio por causa :

○ do desafio 
○ da chance de ser patrão de alguém

○ da liberdade de explorar novas idéias.

Percebe-se que o quadro psicológico que surge na visão dos estudiosos é algo conflitante e confuso. No entanto, parece que uma motivação de realização particularmente alta é um aspecto importante na personalidade empreendedora mas, a autonomia, a independência e a tomada de risco moderado são também fatores contribuintes.

\section{QUALIDADES PESSOAIS DO EMPREENDEDOR}

Para ser um empreendedor de sucesso é preciso ter uma série de qualidades pessoais. Essas qualidades podem ser inatas, isto é, podem nascer com o indivíduo. Ou podem ser adquiridas através do estudo e da prática.

Para NAISBITT (1989), um empreendedor com sucesso tem os seguintes atributos:

a. "Orientação Própria $\rightarrow$ Sentem-se absolutamente à vontade como seu próprio chefe, auto-disciplinado;

b. Auto incentivo $\rightarrow$ Acredita na sua própria idéia quando mais ninguém acredita e é capaz de alimentar seu próprio entusiasmo;

c. Orientação para a Ação $\rightarrow$ Não se satisfaz com grandes idéias comerciais. O mais importante é o desejo intenso de realizar, atualizar e transformar seu sonho em realidade;

d. Alto Nível de Energia $\rightarrow$ É emocional, mental e fisicamente capaz de trabalhar por um longo e intenso período de tempo;

e. Tolerância com a Incerteza $\rightarrow$ Os empreendedores bem sucedidos só assumem riscos calculados (se possível); não obstante, é preciso que sejam capazes de assumir algum risco. Os empreendedores procuram independência, desafio, realização e justa compensação;

f. Compensação $\rightarrow$ As pessoas, às vezes, iniciam seus próprios negócios porque acham que seus esforços, dentro da organização, não foram satisfatoriamente recompensados;

g. Independência $\rightarrow$ Embora procure compensação eqüitativa, a maioria dos empreendedores não é obcecada por dinheiro;

h. Desafio $\rightarrow$ Algumas pessoas trabalham por conta própria, pois é o único meio pelo qual podem satisfazer sua necessidade de desafio;

i. Realização $\rightarrow$ Concorda-se geralmente, que os empreendedores buscam realização, ao passo que os gerentes bem sucedidos desejam o poder."

O autor concluiu dizendo que o empreendedor é simplesmente motivado por necessidades pessoais. 
AZEVEDO (1992:17), aponta dez qualidades que caracterizam a personalidade empreendedora, a saber:

1. "Capacidade de Assumir Riscos $\rightarrow$ É ter coragem de assumir desafios, de tentar um novo empreendimento, de buscar, por si só, os melhores caminhos, é ter autodeterminação.

2. Habilidade para Identificar Oportunidades $\rightarrow$ É perceber, no momento certo, as condições propícias para a realização de um bom negócio. É saber aproveitar as oportunidades que mercado oferece.

3. Conhecimento do Ramo Empresarial $\rightarrow$ É ter experiência prática no negócio que pretende explorar. É obter informações em publicações especializadas, em centros de tecnologias ou de referências de outras pessoas que tem empreendimentos semelhantes.

4. Senso de Organização $\rightarrow$ É ser capaz de utilizar os recursos disponíveis de forma lógica, racional e organizada.

5. Disposição para tomar Decisões $\rightarrow$ É estar bem informado, analisar friamente a situação e avaliar as alternativas para poder escolher a solução mais adequada.

6. Faculdade de Liderar $\rightarrow$ É a capacidade de definir e orientar a realização de tarefas, de combinar métodos e procedimentos práticos, incentivar as pessoas para alcançar os objetivos almejados e produzir o relacionamento equilibrado da equipe de trabalho, em torno do empreendimento.

7. Talento para Empreender $\rightarrow$ É a capacidade de transformar idéias em fatos concretos e dinâmicos. É ter um certo inconformismo diante das atividades rotineiras.

8. Independência Pessoal $\rightarrow$ É a qualidade daquelas pessoas que procuram ser seus próprios patrões.

9. Otimismo $\rightarrow$ É a capacidade natural, que certas pessoas possuem, de enxergar, principalmente, o sucesso, em vez de imaginar e temer os possíveis fracassos.

10. Tino Empresarial $\rightarrow$ É um sexto sentido que determinadas pessoas possuem. É ter prudência de se envolver com a organização em todos os sentidos, da forma mais completa possível, desde a fase da sua criação."

XAVIER (1994), menciona as características acima discriminadas. No entanto, critica o AZEVEDO, quando comenta: “como certamente nenhum de nós é esse super-homem, resta-nos fazer um exercício de auto-análise para saber em que grau será para nós motivo de satisfação ou de transtorno possuir um negócio próprio”. Cita também, algumas características do empreendedor, quais sejam:

- Iniciativa;

- Bom relacionamento com os outros;

- Motivação;

- Persistência; 
- Otimismo;

- Disciplina;

- Aceitação de riscos;

- Agilidade e autoconfiança nas decisões;

- Ambição;

- Vitalidade para o trabalho. (XAVIER, 1994:84)

Convém ressaltar que apesar das críticas feitas pelo autor no que concerne aos parâmetros citados por AZEVEDO, percebe-se que estas características estão contidas naquelas.

\section{MITOS DE EMPREENDEDOR}

PINCHOT (1989:55), afirma que,

"Existem mitos generalizados a respeito dos entrepreneurs; quando são levados para o cenário corporativo, eles impedem idéias claras sobre os intrapreneurs e seu relacionamento com a organização. (...) Se esses mitos fossem verdadeiros, seria impossível utilizar tipos empreendedores dentro da corporação. Felizmente eles não o são."

Dentre esses mitos, o autor destaca:

- MITO No 1: "A principal motivação do entrepreneur é o desejo de riqueza." (Ibidem, 56)

○ O dinheiro não é o incentivo ao esforço para o verdadeiro "entrepreneur", mas sim a medição do seu sucesso.

- MITO No 2: "Entrepreneurs assumem riscos muito altos." (Ibidem, 57)

- Estudos efetuados por David McClelland e outros mostram que os "entrepreneurs" bem-sucedidos escolhem metas desafiadoras, mas também fazem tudo o que podem para reduzir o risco.

- MITO $N^{\circ}$ 3: "O entrepreneurs age impulsivamente porque carece de talentos analíticos." (Ibidem, 59)

- Seria impossível trabalhar dentro do sistema corporativo se fossem totalmente intuitivos em suas tomadas de decisão. $O$ fato dos "entrepreneurs" possuírem talentos intuitivos e a disposição de usá-los não implica falta de talentos analíticos.

- MITO N 4: "Os entrepreneurs são amorais". (Ibidem, 59)

- Talvez a mais gritante semelhança entre todas as descrições que os capitalistas de risco fazem do "entrepreneurs", seja a sua insistência em dizer que honestidade e integridade são características do "entrepreneurs" de sucesso. 
- MITO No 5: “Os entrepreneurs são construtores de impérios sedentos de poder." (Ibidem, p. 61)

○ os “entrepreneurs" não são levados por uma necessidade de poder; sua motivação se origina, em vez disso, de uma extremamente alta necessidade de realização.

Os mitos existem, mas diante do exposto, fica evidente que os temores devem ser desfeitos, quanto a se usar tipos empreendedores dentro da corporação.

\section{FATORES INIBIDORES DO POTENCIAL EMPREENDEDOR}

De acordo com DEGEN (1989:10), "há vários fatores que inibem o surgimento de novos empreendedores". Dentre elas, destaca:

a) Imagem Social - todo empreendedor que deseja ter sucesso precisa estar disposto a, no início do empreendimento, desenvolver ele próprio, todas as atividades inerentes ao seu negócio. No entanto, muitos pensam que após terem galgado uma boa posição na condição de empregados, sua imagem social poderá ser prejudicada, frente às tarefas necessárias para iniciar um novo negócio. Por esta razão, preferem continuar no "conforto" do emprego.

b) Disposição para assumir riscos - é a qualidade mais importante do verdadeiro empreendedor. O seu sucesso está na capacidade de conviver com eles e sobreviver a eles. É preciso aprender a admirá-los, pois fazem parte de qualquer atividade.

c) Capital Social - o autor chama de "capital social", o que todos nós herdamos da nossa formação familiar, religiosa e escolar.

"São os valores e idéias que subliminarmente nos foram incutidos por nossos pais, professores, amigos e outros que influenciaram na nossa formação intelectual e que, inconscientemente, orientam nossas vidas".

\section{A IMPORTÂNCIA DO EMPREENDEDOR NA FORMAÇÃO DA RIQUEZA DO PAÍS}

Sabe-se que o Brasil vem atravessando graves problemas sócio-econômicos e que o melhor recurso de que dispomos para solucionar esses problemas é a liberação da criatividade dos empreendedores, através da livre iniciativa, para produzir os bens e serviços que constituem a riqueza do país.

COLE, citado por DEGEN (1989), descreveu a contribuição dos empreendedores, na formação da riqueza do país, como processo de “destruição criativa”. Este processo que, é “o impulso fundamental que aciona e mantém em marcha o motor capitalista", gera constantemente novos produtos, novos métodos de produção e novos mercados; 
revoluciona sempre a estrutura econômica, destrói sem cessar a antiga e, continuamente, cria uma nova.

Para LEITE (1992:21),

"A importância dos empreendedores, principalmente daqueles que empreendem pequenos negócios para a economia de qualquer nação, é fundamental. Quando os empreendimentos são iniciados, seus idealizadores normalmente têm um elevado espírito empreendedor. Contudo, como mantê-lo quando a organização cresce?"

O autor cita o exemplo do fundador da Apple, Mr. Jobs, que terminou saindo da empresa, pois afirmava que o empreendimento havia crescido demais e estava sufocando o seu espírito empreendedor. No entanto, partiu para a montagem de outra empresa - Next - que hoje está entre as maiores do ramo de computadores e software's dos EUA.

Ele considera o empreendedor como:

"Indivíduo ou grupo de indivíduos que toma a iniciativa de criar uma nova empresa. O empreendedor/criador de empresas, deve participar do processo de criação da empresa e concretizar a sua iniciativa empresarial, legalizando a empresa criada e participando positivamente de sua direção". (LEITE, 1992:88)

Em suma, o empreendedor não é apenas, aquele indivíduo que fundou ou que é dono da empresa, mas também aquele que cria, inova e tem idéias inovadoras, e que se postas em prática trarão resultados eficazes e logicamente sucesso para a empresa, contribuindo assim, para o desenvolvimento do país.

\section{FORMAÇÃO E DESENVOLVIMENTO DO EMPREENDEDOR}

“Apesar de já estarmos no início da década de 90, ainda parece muito remota a idéia de se descrever historicamente os antecedentes das experiências brasileiras, no que diz respeito à formação de empreendedores". (PEREIRA, 1990:68)

Sabe-se que tanto a nível institucional, como em termos de entidades empresariais, pouco esforços tem sido observado com relação à formação destes empreendedores, tanto na fase de criação como na de pós-criação dos empreendimentos. 


\section{INFORMAÇÕES LEVANTADAS}

Diante das dificuldades de se contatar o universo das microempresas que participaram do Programa, optou-se pela aplicação do instrumento de investigação a quinze delas, selecionadas aleatoriamente.

Foram utilizados dois questionários, um deles direcionado no sentido do estabelecimento do perfil do empreendedor e outro com perguntas estruturadas de modo a definir as características básicas do empreendedor, as causas do sucesso de um empreendimento do porte dos que consubstanciam o Programa PROVE, a expectativa quanto ao futuro dos negócios e o papel do governo como suporte da atividade produtiva.

\section{Quadro - 1}

O empreendedor - Gênero, Idade, Estado Civil, Grau de Instrução

\begin{tabular}{c|c|c|c|c|}
\hline Micro Empresa & Gênero & Idade & Estado Civil & Grau de Instrução \\
\hline 1 & M & 67 & Casado & $2^{\circ}$ Grau Incompleto \\
\hline 2 & F & 35 & Casada & $1^{\circ}$ Grau Incompleto \\
\hline 3 & F & 40 & Separado & $2^{\circ}$ Grau Incompleto \\
\hline 4 & F & 32 & Casada & $1^{\circ}$ Grau Incompleto \\
\hline 5 & M & 41 & Casado & $2^{\circ}$ Grau Incompleto \\
\hline 6 & F & 55 & Casada & $1^{\circ}$ Grau Incompleto \\
\hline 7 & F & 40 & Casada & $2^{\circ}$ Grau \\
\hline 8 & F & 26 & Solteira & $2^{\circ}$ Grau \\
\hline 9 & M & 43 & Casado & $1^{\circ}$ Grau Incompleto \\
\hline 10 & M & 41 & Casado & $3^{\circ}$ Grau \\
\hline 11 & M & 41 & Casado & $3^{\circ}$ Grau Incompleto \\
\hline 12 & F & 59 & Casada & $1^{\circ}$ Grau Incompleto \\
\hline 13 & F & 60 & Viúva & $1^{\circ}$ Grau \\
\hline 14 & M & 48 & Casado & $1^{\circ}$ Grau \\
\hline 15 & F & 30 & Casada & \\
\hline
\end{tabular}

\section{Quadro - 2}

Características mais Importantes do Empreendedor

\begin{tabular}{c|l}
\hline Micro Empresa & Características \\
\hline 1 & \multicolumn{1}{|c}{$\begin{array}{l}\text { Talento para empreender } \\
\text { Tino empresarial Capacidade para assumir risco } \\
\text { Otimismo }\end{array}$} \\
\hline 2 & $\begin{array}{l}\text { Conhecer o ramo empresarial Talento para empreender } \\
\text { Habilidade para identificar oportunidades }\end{array}$ \\
\hline 3 & $\begin{array}{l}\text { Habilidade para identificar oportunidades } \\
\text { Conhecer o ramo empresarial } \quad \text { Talento para empreender }\end{array}$ \\
\hline 4 & $\begin{array}{l}\text { Otimismo } \\
\text { Habilidade para identificar oportunidades }\end{array}$ \\
\hline 5 & $\begin{array}{l}\text { Otimismo } \\
\text { Tino empresarial }\end{array}$ \\
\hline 6 & $\begin{array}{l}\text { Otimismo } \\
\text { Senso de organização de organização }\end{array}$ \\
\hline
\end{tabular}




\begin{tabular}{c|ll}
\hline 7 & $\begin{array}{l}\text { Tino empresarial } \\
\text { Liderança }\end{array}$ & Senso de organização \\
\hline 8 & $\begin{array}{l}\text { Senso de Organização } \\
\text { Conhecer o ramo empresarial }\end{array}$ & Capacidade de assumir risco \\
\hline 9 & $\begin{array}{l}\text { Otimismo } \\
\text { Independência pessoal }\end{array}$ \\
\hline 10 & $\begin{array}{l}\text { Capacidade de assumir risco } \\
\text { Disposição para tomar decisão }\end{array}$ \\
\hline 11 & $\begin{array}{l}\text { Habilidade para identificar oportunidades } \\
\text { Capacidade para assumir risco }\end{array}$ & Disposição para tomar decisão pessoal \\
\hline 12 & $\begin{array}{l}\text { Otimismo } \\
\text { Capacidade para assumir risco }\end{array}$ \\
\hline 13 & $\begin{array}{l}\text { Talento para empreender } \\
\text { Tino empresarial }\end{array}$ \\
\hline 14 & $\begin{array}{l}\text { Otimismo otimismo } \\
\text { Talento para empreender }\end{array}$ \\
\hline 15 & $\begin{array}{l}\text { Conhecer o ramo empresarial } \\
\text { Talento para empreender }\end{array}$ \\
\hline
\end{tabular}

Quadro - 3

Características menos Importantes do Empreendedor

\begin{tabular}{c|l}
\hline Micro Empresa & \multicolumn{1}{c}{ Características } \\
\hline 1 & $\begin{array}{l}\text { Independência pessoal } \\
\text { Senso de organização }\end{array}$ \\
\hline 2 & $\begin{array}{l}\text { Tino empresarial } \\
\text { Independência pessoal }\end{array}$ \\
\hline 3 & $\begin{array}{l}\text { Liderança } \\
\text { Independência pessoal }\end{array}$ \\
\hline 4 & $\begin{array}{l}\text { Liderança } \\
\text { Tino empresarial }\end{array}$ \\
\hline 5 & $\begin{array}{l}\text { Independência pessoal } \\
\text { Conhecer o ramo empresarial }\end{array}$ \\
\hline 6 & $\begin{array}{l}\text { Independência pessoal } \\
\text { Conhecer o ramo empresarial }\end{array}$ \\
\hline 8 & $\begin{array}{l}\text { Independência pessoal } \\
\text { Conhecer o ramo empresarial }\end{array}$ \\
\hline 10 & $\begin{array}{l}\text { Independência pessoal } \\
\text { Liderança }\end{array}$ \\
\hline Conhecer o ramo empresarial \\
Liderança
\end{tabular}




\begin{tabular}{c|l}
\hline 11 & $\begin{array}{l}\text { Conhecer o ramo empresarial } \\
\text { Independência pessoal }\end{array}$ \\
\hline 12 & $\begin{array}{l}\text { Independência pessoal } \\
\text { Liderança }\end{array}$ \\
\hline 13 & $\begin{array}{l}\text { Independência pessoal } \\
\text { Conhecer o ramo empresarial }\end{array}$ \\
\hline 14 & $\begin{array}{l}\text { Independência pessoal } \\
\text { Conhecer o ramo empresarial }\end{array}$ \\
\hline 15 & $\begin{array}{l}\text { Conhecer o ramo empresarial } \\
\text { Liderança }\end{array}$ \\
\hline
\end{tabular}

Quadro-4

Expectativa quanto ao Futuro dos Negócios

\begin{tabular}{c|c|c|c}
\hline Micro Empresa & Diminuir de Ritmo & Permanecer como está & Aumentar de ritmo \\
\hline 1 & & & $\mathrm{X}$ \\
\hline 2 & & & $\mathrm{X}$ \\
\hline 3 & & & $\mathrm{X}$ \\
\hline 4 & & & $\mathrm{X}$ \\
\hline 5 & & & $\mathrm{X}$ \\
\hline 6 & & & $\mathrm{X}$ \\
\hline 7 & & & $\mathrm{X}$ \\
\hline 8 & & & $\mathrm{X}$ \\
\hline 9 & & & $\mathrm{X}$ \\
\hline 10 & & & $\mathrm{X}$ \\
\hline 11 & & & $\mathrm{X}$ \\
\hline 12 & & & $\mathrm{X}$ \\
\hline 13 & & & $\mathrm{X}$ \\
\hline 14 & & & $\mathrm{X}$ \\
\hline 15 & & & \\
\hline
\end{tabular}

Quadro - 5

Papel do Governo como Suporte da Atividade Produtiva

\begin{tabular}{c|l}
\hline Micro Empresa & \multicolumn{1}{c}{ O que o governo pode/deve fazer pela empresa } \\
\hline 1 & - \\
\hline 2 & $\begin{array}{l}\text { Reduzir encargos/juros } \\
\text { Promover a regularização da área agrícola }\end{array}$ \\
\hline 3 & $\begin{array}{l}\text { Reduzir encargos/juros } \\
\text { Promover a regularização da área agrícola }\end{array}$ \\
\hline 4 & $\begin{array}{l}\text { Incentivar a produção de matéria prima } \\
\text { Facilitar o acesso viário à área agrícola }\end{array}$ \\
\hline
\end{tabular}




\begin{tabular}{l|l}
\hline 5 & Ampliar a oferta de crédito \\
\hline 6 & Ampliar a oferta de crédito \\
\hline 7 & $\begin{array}{l}\text { Promover a regularização da área agrícola } \\
\text { Reduzir encargos/juros }\end{array}$ \\
\hline 8 & Disponibilizar mais assistência técnica \\
\hline 10 & - \\
\hline 11 & Reduzir a burocracia dos financiamentos \\
\hline 12 & $\begin{array}{l}\text { Ampliar as linhas de crédito } \\
\text { Disponibilizar mais assistência técnica }\end{array}$ \\
\hline 13 & Ampliar o volume de empréstimos \\
\hline 14 & Promover a regularização da área agrícola \\
\hline 15 & $\begin{array}{l}\text { Promover a regularização da área agrícola } \\
\text { Ampliar o volume de crédito }\end{array}$ \\
\hline
\end{tabular}

\section{5 - CONCLUSÕES POSSÍVEIS}

Levando-se em conta as informações inicialmente apresentadas quando da inscrição do Programa no ciclo de premiação de 1997, o que foi possível complementar com a visita, in loco, após a seleção prévia do mesmo e com a pesquisa posterior, é possível inferir-se algumas conclusões:

- Programa, originado de um esforço do Governo do Distrito Federal para promover o micro empresário rural, vem se consolidando ao longo dos dois anos de funcionamento, através da ampliação das microunidades de produção em funcionamento e da efetiva contribuição ao esforço de geração de emprego e renda, patrocinado pelo GDF;

- A predominância, inicial, de mulheres empreendedoras persiste, com tendência a acentuar-se. Hoje elas representam $60 \%$ da comunidade de empreendedores vinculados ao PROVE;

- Verificar-se uma elevada concentração dos empreendedores na faixa etária compreendida entre os limites de 30 e 50 anos onde se situam $67 \%$ de total deles;

- Praticamente todos eles são casados e a grande maioria (53\%) possui, apenas, o $1^{\circ}$ grau no que diz respeitos à escolaridade;

- Constata-se uma satisfação generalizada com a iniciativa do GDF e a totalidade dos entrevistados acredita que seus negócios vão se expandir nos próximos anos;

- As mesmas características que definem o empreendedor, relacionadas na literatura disponível, são as citadas pelos entrevistados;

Dentre essas características, admitem como as mais importantes: 
- Otimismo;

- Talento para empreender;

- Capacidade de assumir riscos;

- Tino empresarial;

- Senso de organização;

Como as menos importantes, consideram:

- Independência pessoal;

- Conhecimento, prévio, do ramo;

- Liderança;

Com relação às ações do governo, que poderiam ser dinamizadas com vistas á ampliação de seus negócios, apontaram:

- Uma política de regularização das áreas que utilizam para a produção;

- Ampliação do crédito;

- Redução dos encargos tributários. 


\section{BIBLIOGRAFIA}

ANSOFF, Igor - Do Planejamento Estratégico à Administração Estratégica. São Paulo: Atlas, 1983

AQUINO, Cleber - História Empresarial Vivida. São Paulo: Gazeta Mercantil, 1986

AZEVEDO, João Humberto - Manual de Iniciação Empresarial. Brasília: SEBRAE, 1987

CHIAVENATO, Idalberto - Vamos Abrir um Novo Negócio?. São Paulo: Makron Bookos, 1995

DRUCKER, Peter F. - Administração Para o Futuro. São Paulo: Pioneira, 1992

GERBER, Michael E. - O Mito do Empreendedor. São Paulo: McGraw-Hill do Brasil, 1983

GUEDES, Maria D. - Quantificação da Relevância dos fatores que Caracterizam o Perfil do Empreendedor. Dissertação (Mestrado em Administração), UFPB, 1995

LEAL, Ricardo P.C. e WOLKEMA, Roger - Espírito Empreendedor. Anais ENANPAD, Belo Horizonte, 1988

RESNIK, Paul - A Bíblia da Pequena Empresa. São Paulo: McGraw-Hill do Brasil, 1990

SALOMON, Steven - A Grande Importância da Pequena Empresa. Rio de Janeiro: Nórdica, 1986

SANTANA, João. - Como Entender o Mundo dos Negócios. Brasília: SEBRAE, 1993

SCHUMPETER, Joseph A. - Teoria do Desenvolvimento Econômico. São Paulo: Abril Cultural, 1992

SILVA, Miguel J. - Novo Tratamento Tributário às Micro e Pequenas Empresas. Brasília: Diário Oficial em 06/12/96

TORRES, Rômulo S. - O Processo de Formação de Empreendedores nas Empresas de Base Tecnológica Ligadas às Incubadoras Tecnológicas do Nordeste. Dissertação (Mestrado em Administração), UFPB, 1995

VRIES, M. F. Kets - A Personalidade Empreendedora. São Paulo: Nacional, 1996 